\title{
Measuring the Effect of Cutaneous Neurofibromas on Quality of Life in Neurofibromatosis Type 1
}

Sheilagh Maguiness, MD, ${ }^{*}$ Yemima Berman, BMBS, PhD, ${ }^{*}$ Nathan Rubin, MSc, Melissa Dodds, MD, Scott R. Plotkin, MD, PhD, Claire Wong, MGC, and Christopher Moertel, MD, on behalf of the REiNS International Collaboration

Neurology ${ }^{\circledR}$ 2021;97:S25-S31. doi:10.1212/WNL.0000000000012427
Correspondence Dr. Berman Yemima.berman@ health.nsw.gov.au

\begin{abstract}
Objective

In order to explore the use of Skindex scoring in patients with neurofibromatosis type 1 (NF1) across multiple clinical sites and inform design of additional quality of life measures, we analyzed correlations between Skindex, site, and clinical measures for 79 patients with NF1 from specialized clinics in Sydney, Australia (Royal North Shore Hospital [RNS]) and Minneapolis, Minnesota (University of Minnesota [UMN]).
\end{abstract}

\section{Methods}

The relationship between clinical factors and Skindex scores were explored by clinic site and overall.

\section{Results}

A total of 40 participants were recruited from RNS and 39 from UMN. Female sex, total number of cutaneous neurofibroma (cNF), and whether cNF were present on the face correlated highly with Skindex and not Riccardi scores. The UMN site had lower average scores, but these differences were almost entirely removed after adjusting for age, sex, facial cNF, and total cNF number.

\section{Conclusions}

The development of cNF in adolescence and adulthood in NF1 often leads to progressive disfigurement and discomfort and is among one of the most common reasons for patients to seek medical treatment. Skindex has been used to assess skin-related quality of life in NF1 previously but is not specific to NF1. These findings highlight the need for a low threshold for referral to dermatologists for all patients with NF1 regardless of the severity of disease. The finding that facial $\mathrm{cNF}$ and higher total number of $\mathrm{cNF}$ correlates with poorer skin-related quality of life may benefit design of more specific NF1 skin-related quality of life measures.
*These authors contributed equally.

From the Department of Dermatology (S.M., M.D.), Biostatistics Core, Masonic Cancer Center (N.R.), and Department of Pediatrics (C.M.), University of Minnesota, Minneapolis; Department of Clinical Genetics (Y.B., C.W.), Royal North Shore Hospital; Faculty of Medicine (Y.B.), University of Sydney, Australia; and Department of Neurology and Cancer Center (S.R.P.), Massachusetts General Hospital, Boston.

Go to Neurology.org/N for full disclosures. Funding information and disclosures deemed relevant by the authors, if any, are provided at the end of the article. 


\section{Glossary}

$\mathrm{cNF}=$ cutaneous neurofibroma; NF1 = neurofibromatosis type 1; QoL = quality of life; RNS = Royal North Shore Hospital; UMN = University of Minnesota.

Neurofibromatosis type 1 (NF1) is a rare progressive multisystem genetic disorder of tumor susceptibility. ${ }^{1,2}$ Patients are predisposed to benign and malignant tumors of the peripheral nervous system and CNS, breast, thyroid, and adrenal gland. ${ }^{1}$ NF1 is highly variable. Potential complications include disfiguring and disabling plexiform neurofibromas, orthopedic abnormalities, autism, and variable learning disability. ${ }^{2,3} \mathrm{~Pa}-$ tients may experience minimal effect on their functioning, whereas others struggle with significant burden and overall reduction in health-related quality of life (QoL). ${ }^{4-8}$ Patients with more visible NF1 manifestations report greater reduction in QoL than those with less visible manifestations..$^{9-11}$
Most people with NF1 will develop cutaneous neurofibroma (cNF) by age $30 .{ }^{12}$ The number and volume of cNF increase with age, but may vary in different regions of the body. ${ }^{13,14}$ The average number of $\mathrm{cNF}$ has been seen to increase from approximately 10 under the age of 10 to over 1,000 from the 40th decade onward. ${ }^{9,14}$ Although the number of neurofibromas may vary widely between patients, and within families, most are on the trunk (60\%), with approximately $10 \%$ on the head and neck. ${ }^{13,14} \mathrm{cNF}$ often lead to progressive disfigurement and discomfort for affected patients, and are among one of the most common reasons for patients to seek medical treatment. ${ }^{14,15}$

Table 1 Demographic and Clinical Characteristics

\begin{tabular}{|c|c|c|c|c|}
\hline Measure & Overall $(n=79)$ & RNS $(n=40)$ & UMN (n = 39) & $p$ Value \\
\hline Total Skindex-29 & 30.7 (25.9) & $38.8(25.6)$ & $22.4(23.9)$ & $0.004^{a}$ \\
\hline Physical/symptoms & $31.1(24.0)$ & $37.1(24.6)$ & $24.9(21.9)$ & $0.022^{a}$ \\
\hline Emotions & 39.7 (32.6) & $51.6(32.2)$ & $27.4(28.4)$ & $<0.001^{a}$ \\
\hline Functional & $21.5(25.0)$ & $26.7(25.0)$ & $16.2(24.1)$ & 0.060 \\
\hline Itch question & $53.2(32.9)$ & $57.5(33.6)$ & 48.7 (31.9) & 0.237 \\
\hline Age, y & $38.7(12.7)$ & $40.7(12.4)$ & $36.7(12.8)$ & 0.159 \\
\hline Male, n (\%) & $32(40.5)$ & $15(37.5)$ & $17(43.6)$ & 0.650 \\
\hline Cutaneous NFs, n (\%) & & & & $0.012^{\mathrm{a}}$ \\
\hline 0 & $6(7.6)$ & $0(0)$ & $6(15.4)$ & \\
\hline $1-19$ & $15(19.0)$ & $6(15)$ & $9(23.1)$ & \\
\hline $20-99$ & $17(21.5)$ & $11(27.5)$ & $6(15.4)$ & \\
\hline $100-500$ & $11(13.9)$ & $2(5.0)$ & $9(23.1)$ & \\
\hline$>500$ & $29(36.7)$ & $20(50.0)$ & $9(23.1)$ & \\
\hline Missing & $1(1.3)$ & $1(2.5)$ & $0(0)$ & \\
\hline Face, $\mathrm{n}(\%)$ & $41(52)$ & $18(45)$ & $23(59)$ & 0.365 \\
\hline Riccardi, n (\%) & & & & $0.010^{\mathrm{a}}$ \\
\hline Minimal & $2(2.5)$ & $1(2.5)$ & $1(2.6)$ & \\
\hline Mild & $16(20.3)$ & $14(35)$ & $1(5.1)$ & \\
\hline Moderate & $41(52)$ & $18(45)$ & $23(59.0)$ & \\
\hline Severe & $18(22.8)$ & $7(17.5)$ & $11(28.2)$ & \\
\hline Missing & $2(2.5)$ & $0(0)$ & $2(5.1)$ & \\
\hline
\end{tabular}

Abbreviations: NF = neurofibromatosis; RNS = Royal North Shore Hospital; UMN = University of Minnesota.

Continuous measures were summarized using mean (SD) and compared with the 2-sample $t$ test. The $p$ values for the binary categorical variables (sex, face) are from the Fisher exact test. The $p$ values for the ordinal variables (number of cutaneous NFs, Riccardi) are from the nonparametric Mann-Whitney $U$ test. a Significant at $p<0.05$ level. 
Table 2 Relationship Between Clinical Factors and Skindex Scores for all Domains and by Site

\begin{tabular}{|c|c|c|c|c|c|c|c|c|}
\hline \multirow[b]{2}{*}{ Both sites } & \multicolumn{2}{|c|}{ Total skindex } & \multicolumn{2}{|l|}{ Physical } & \multicolumn{2}{|l|}{ Emotions } & \multicolumn{2}{|l|}{ Functional } \\
\hline & Statistic & $p$ Value & Statistic & $p$ Value & Statistic & $p$ Value & Statistic & $p$ Value \\
\hline Age, $r$ & 0.13 & 0.242 & 0.24 & 0.035 & 0.08 & 0.51 & 0.11 & 0.333 \\
\hline Sex, mean & $F: 37.8$ & 0.001 & F: 36.3 & 0.016 & F: 48.8 & 0.001 & $F: 27.8$ & 0.002 \\
\hline Number of $\mathrm{cNF}, \mathrm{r}_{\mathrm{s}}$ & 0.50 & $<0.001$ & 0.46 & $<0.001$ & 0.46 & $<0.001$ & 0.48 & $<0.001$ \\
\hline Facial NF, mean & Y: 38.9 & 0.002 & Y: 38.0 & 0.007 & Y: 48.0 & 0.015 & Y: 29.2 & 0.003 \\
\hline Riccardi score, $r_{s}$ & -0.10 & 0.371 & 0.00 & 0.994 & -0.16 & 0.157 & -0.05 & 0.696 \\
\hline \multicolumn{9}{|l|}{ UMN } \\
\hline Age, $r$ & 0.19 & 0.258 & 0.32 & 0.044 & 0.12 & 0.479 & 0.14 & 0.409 \\
\hline Sex, mean & $\mathrm{F}: 28.0$ & 0.078 & $F: 30.7$ & 0.049 & F: 34.0 & 0.089 & $F: 20.5$ & 0.170 \\
\hline Number of cNF, $r_{s}$ & 0.63 & $<0.001$ & 0.46 & 0.003 & 0.62 & $<0.001$ & 0.60 & $<0.001$ \\
\hline Facial NF, mean & $Y: 32.9$ & $<0.001$ & $Y: 30.7$ & 0.035 & $\mathrm{Y}: 41.1$ & $<0.001$ & $Y: 26.0$ & $<0.001$ \\
\hline Riccardi score, $r_{s}$ & 0.06 & 0.713 & 0.05 & 0.760 & 0.05 & 0.779 & 0.16 & 0.354 \\
\hline \multicolumn{9}{|l|}{ RNS } \\
\hline Age, $r$ & 0.00 & 0.985 & 0.10 & 0.533 & -0.07 & 0.662 & 0.02 & 0.883 \\
\hline Sex, mean & $F: 46.4$ & 0.015 & F: 41.1 & 0.177 & F: 61.9 & 0.010 & F: 34.3 & 0.008 \\
\hline Number of cNF, $r_{s}$ & 0.28 & 0.083 & 0.36 & 0.024 & 0.17 & 0.308 & 0.26 & 0.112 \\
\hline Facial NF, mean & Y: 46.5 & 0.095 & Y: 47.2 & 0.021 & Y: 56.8 & 0.357 & Y: 33.3 & 0.140 \\
\hline Riccardi score, $r_{s}$ & -0.06 & 0.725 & 0.05 & 0.761 & -0.14 & 0.376 & -0.07 & 0.667 \\
\hline
\end{tabular}

Abbreviations: cNF = cutaneous neurofibroma; NF = neurofibromatosis; RNS = Royal North Shore Hospital; UMN = University of Minnesota.

Age is summarized by Pearson correlation. Sex and facial NF are summarized by means and tested by $t$ test. Riccardi score and number of NF are tested by nonparametric Spearman correlation.

This study presents correlations between Skindex and clinical characteristics collected from clinics in Sydney, Australia, and Minneapolis, Minnesota. The feasibility of combining data across sites with different clinical characteristics and demographics is examined.

\section{Methods}

\section{Participants, Standard Protocol Approvals, Registrations, and Patient Consents}

Patients attending an NF1 skin clinic at Royal North Shore Hospital (RNS) or an NF1 clinic from the University of Minnesota (UMN) were invited to participate. At RNS, the primary focus is treatment of cutaneous manifestations of $\mathrm{NF} 1$ in patients over the age of 18 ; at UMN, the clinic focuses on general management and care. Before participation, all patients provided written informed consent. The Human Research Ethics Committees of RNS and the UMN approved the protocol (LNR/15/HAWKE/360; STUDY00001191). All study information was collected at a single patient visit.

\section{Survey Instrument}

Participants were asked to complete the paper form of the Skindex-29 questionnaire. ${ }^{16,17}$ Skindex-29 is one of the most commonly used dermatology-specific QoL instruments. Skindex-29 responds to change over time and has been used in clinical trials in several diseases. ${ }^{18,19}$ This instrument includes 29 questions that assess the physical (7 question), emotional (10 questions), and functional (11 questions) effects of skin conditions; there is one additional question to assess itch. The response to each question on the Skindex was coded $(0=$ never; $25=$ rarely; $50=$ sometimes; $75=$ often; $100=$ all the time $)$.

\section{Clinical Assessment}

$\mathrm{cNF}$ were assessed by the treating physician. The number of $\mathrm{cNF}$ $(0,1-19,20-99,100-500$, or $>500)$, presence or absence of $\mathrm{cNF}$ on the face, and Riccardi score ${ }^{20}$ of severity were collected. The Riccardi NF1 severity scale ranges from levels 1 to 4 , where level 1 , minimal NF1, is the presence of few features; level 2, mild $\mathrm{NF} 1$, involves enough stigmata to make the disease obvious but with no compromise of health; level 3, moderate NF1, is associated with significant but well-managed compromise of health; and level 4, severe NF1, has serious intractable compromise of health, managed or treated with difficulty.

\section{Statistical Considerations}

Patient demographics, other relevant clinical information, and Skindex total score and subdomain score (physical, emotions, 


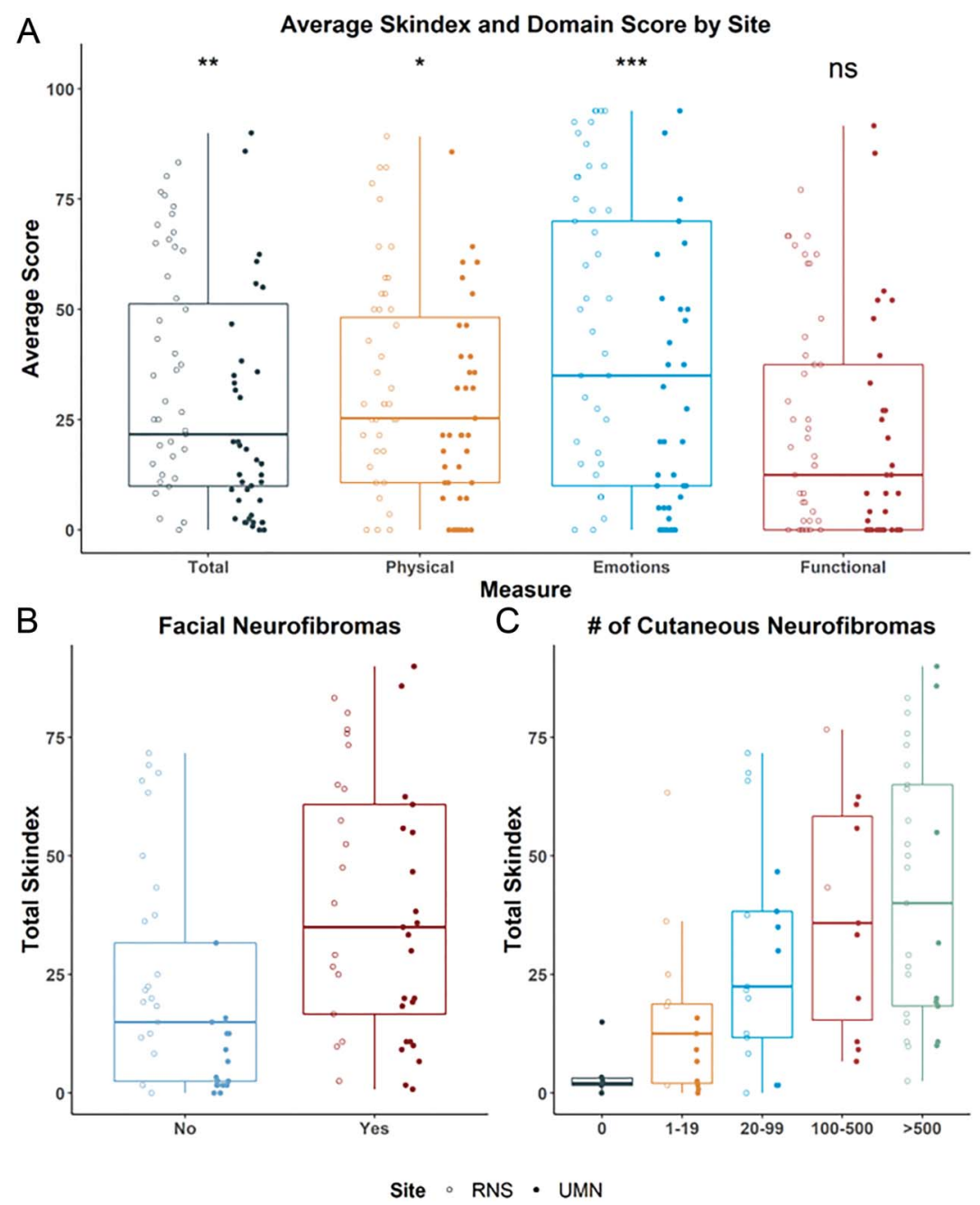

(A) Average Skindex and domain score by site. (B) Skindex by presence of facial cNF. (C) Number of cutaneous neurofibromas. ${ }^{*} p<0.05 ; * \star p<0.01 ; * \star * p<$ 0.001. ns = not significant; RNS $=$ Royal North Shore Hospital; UMN = University of Minnesota. function, and itch) were summarized descriptively. Comparisons between sites were made using 2-sample $t$ tests for continuous measures, Fisher exact tests for binary measures, or Mann-Whitney $U$ test for ordinal measures. The relationship between the clinical factors and Skindex scores was explored by clinic site and overall for each of the Skindex subdomains. Pearson correlation was used to summarize the numeric measures. Spearman correlation was used for ordinal measures and means and $t$ tests were used for binary measures.

Table 3 Linear Regression of Site-Related Differences

\begin{tabular}{|c|c|c|c|c|}
\hline $\begin{array}{l}\text { Skindex } \\
\text { measure }\end{array}$ & $\begin{array}{l}\text { Unadjusted average difference and } \\
95 \% \mathrm{Cl} \text { (UMN - RNS) }\end{array}$ & $\begin{array}{l}\text { Unadjusted } \\
p \text { value }\end{array}$ & $\begin{array}{l}\text { Adjusted average difference and } \\
95 \% \mathrm{CI} \text { (UMN - RNS) }\end{array}$ & $\begin{array}{l}\text { Adjusted } \\
p \text { value }\end{array}$ \\
\hline Total & $-16.4(-27.5,-5.3)$ & 0.004 & $-11.6(-24.7,1.5)$ & 0.081 \\
\hline Physical & $-12.2(-22.7,-1.8)$ & 0.022 & $-8.0(-21.2,5.2)$ & 0.230 \\
\hline Emotions & $-24.2(-37.8,-10.5)$ & $<0.001$ & $-16.8(-32.5,-1.2)$ & 0.036 \\
\hline Functional & $-10.5(-21.5,0.5)$ & 0.060 & $-7.2(-20.7,6.3)$ & 0.292 \\
\hline Itch question & $-8.8(-23.5,5.9)$ & 0.237 & $-2.8(-22.2,16.7)$ & 0.776 \\
\hline
\end{tabular}

Abbreviations: $\mathrm{Cl}$ = confidence interval; RNS = Royal North Shore Hospital; UMN = University of Minnesota.

The average site difference (UMN - RNS), $95 \% \mathrm{Cl}$, and $p$ value for each Skindex measure from the simple linear regression model (unadjusted), as well as the multiple linear regression model (adjusted for age, sex, the numbers of NFs, whether NFs were present of the face, and Riccardi score). 
To account for possible confounding, we used multiple linear regression models to assess whether the average Skindex score differed by site after adjusting for differences in age, sex, the number of cNF, whether cNF were present on the face, and Riccardi score. Separate models were run for the total average score and each subdomain (physical, emotions, functional, itch). The relative importance of each covariate in the regression models was calculated by the relatimpo package in $\mathrm{R}$ (V.2.2), which averages over orderings of sequential R2. ${ }^{21}$ Each covariate in the model has a relative importance score between 0 and 1 , where values closer to 1 represent a larger contribution to the model and the sum of all the scores in the model add up to 1 . There are no guidelines for what cutoff constitutes a high relative importance, as that depends on the specific context of the analysis and the number of covariates in the model.

To assess whether the relationship between the total average Skindex score and the clinical measures significantly differed by site, the interactions between site and the clinical measure were separately tested in a regression model, with only the interaction and main effects of site and the clinical measure as covariates. Analyses were conducted in $\mathrm{R}$ version 3.5.1. $p$ Values less than 0.05 were considered statistically significant.

\section{Data Availability}

Any data not published within this article are available in a public repository.

\section{Results}

A total of 79 patients completed the Skindex survey: 40 from RNS and 39 from UMN. Participant demographics are shown in table 1 . Patients from the UMN site were slightly younger on average (36.7 [12.8] vs 40.7 [12.4]), more likely to be male (44\% vs $38 \%$ ), and more likely to have facial cNF ( $59 \%$ vs $45 \%$ ). Patients from the UMN site also had significantly fewer $\mathrm{cNF}$ and were more likely to have a higher Riccardi score.

The mean total Skindex scores were in the moderate range of severity among the UMN participants, while the RNS participants' mean was in the severe range (mean [SD] 22.4 [21.9] vs 38.8 [25.6], $p=0.004) .{ }^{22}$ There was a weak positive correlation between age and Skindex scores. The correlations are stronger, though still modest, at the UMN site and among the physical domain (table 2). When using data from both sites, the number of $\mathrm{cNF}$ was the most important clinical factor correlating with Skindex score in the regression model (relative importance of between 0.34 and 0.40 , depending on the Skindex domain; figure and table 4). This is followed by sex, facial cNF, and site (figure and table 4). Riccardi score and age are not significantly correlated with Skindex scores in the models. These findings are consistent for all subdomains.
Table 4 Relative Importance of Clinical Factors Correlating With Skindex

\begin{tabular}{|c|c|c|c|c|}
\hline & Total & Physical & Emotions & Functional \\
\hline \multicolumn{5}{|l|}{ Both sites } \\
\hline Number of NF & 0.37 & 0.40 & 0.34 & 0.38 \\
\hline Sex & 0.20 & 0.17 & 0.18 & 0.22 \\
\hline Facial NF & 0.17 & 0.15 & 0.12 & 0.22 \\
\hline Site & 0.15 & 0.14 & 0.18 & 0.09 \\
\hline Riccardi & 0.07 & 0.09 & 0.13 & 0.05 \\
\hline Age & 0.04 & 0.06 & 0.05 & 0.04 \\
\hline \multicolumn{5}{|l|}{ UMN } \\
\hline Number of NF & 0.44 & 0.38 & 0.45 & 0.46 \\
\hline Facial NF & 0.31 & 0.14 & 0.31 & 0.34 \\
\hline Sex & 0.13 & 0.26 & 0.10 & 0.10 \\
\hline Age & 0.06 & 0.13 & 0.07 & 0.07 \\
\hline Riccardi & 0.05 & 0.10 & 0.06 & 0.05 \\
\hline \multicolumn{5}{|l|}{ RNS } \\
\hline Sex & 0.35 & 0.11 & 0.41 & 0.39 \\
\hline Number of NF & 0.22 & 0.24 & 0.20 & 0.22 \\
\hline Riccardi & 0.24 & 0.38 & 0.26 & 0.26 \\
\hline Facial NF & 0.13 & 0.24 & 0.06 & 0.11 \\
\hline Age & 0.05 & 0.03 & 0.08 & 0.02 \\
\hline
\end{tabular}

The relative importance measures of the various clinical factors for the multiple linear regression models for both sites, UMN separately, and RNS separately.

Whereas the average unadjusted difference in Skindex scores between sites was statistically significant, or near significant, adjusting for clinical factors reduced the size of these differences (table 3). After adjustment, the UMN site still had lower scores on average; however, these differences were no longer statistically significant, except in the emotion domain $(p=$ 0.036).

\section{Discussion}

The findings of this study follow previous cohort studies that demonstrate an increase in skin-specific effect in patients with cNF as measured by Skindex, particularly in those with more visible disease. ${ }^{411}$ Facial $\mathrm{cNF}$ and number of cNF yielded a higher effect on the Skindex scores, and this was true at each site. There were some site-specific differences in survey scores in our cohorts. However, when adjusting for sex, number of $\mathrm{cNF}$, facial $\mathrm{cNF}$, and age, the Skindex scores were more consistent.

The overall higher Skindex scores in the RNS cohort are likely to reflect the differing patient populations, with higher skin 
symptomatology in a clinic specializing in cNF skin treatment vs a general NF clinic. QoL was significantly affected by sex, presence of facial $\mathrm{cNF}$, and total number of $\mathrm{cNF}$. Total number and facial involvement were the most important covariates in terms of overall effect across the Skindex domains, with the number of $\mathrm{cNF}$ showing a linear correlation and the greatest relative importance. Interestingly, Riccardi scores did not correlate well across domains, indicating that the Skindex tool should be used independently from Riccardi scores.

The location of neurofibromas is not assessed by existing patient-reported outcome questionnaires including Skindex. Our findings suggest this may be an important variable affecting QoL and should be considered in any future patientreported outcome questionnaires.

Our findings that number of cNF, facial cNF, sex, and age can affect Skindex score suggest these measures will be important to consider in clinical trial design, as such factors could confound unstratified populations during site comparisons.

\section{Acknowledgment}

The authors thank Dominique Pichard for review of this article and the Children's Tumor Foundation for support of the REiNS International Collaboration.

\section{Study Funding}

Research reported in this publication was supported by NIH grant P30 CA77598 utilizing the Biostatistics and Bioinformatics Core shared resource of the Masonic Cancer Center, University of Minnesota, The Children's Tumour Foundation of Australia, and the National Center for Advancing Translational Sciences of the NIH award number UL1-TR002494. The content is solely the responsibility of the authors and does not necessarily represent the official views of the NIH.

\section{Disclosure}

The authors report no disclosures relevant to this article. Go to Neurology.org/ $\mathrm{N}$ for full disclosures.

\section{Publication History}

Received by Neurology October 12, 2020. Accepted in final form April 23, 2021.

Appendix Authors

\begin{tabular}{lll}
\hline Name & Location & Contribution \\
\hline $\begin{array}{ll}\text { Sheilagh M. } \\
\text { Maguiness, MD }\end{array}$ & $\begin{array}{l}\text { Department of } \\
\text { Dermatology, University of } \\
\text { Minnesota, Minneapolis }\end{array}$ & $\begin{array}{l}\text { Drafting/revision of the } \\
\text { manuscript for content, } \\
\text { including medical } \\
\text { writing for content; } \\
\end{array}$ \\
& $\begin{array}{l}\text { study concept or design; } \\
\text { analysis or interpretation } \\
\text { of data }\end{array}$ \\
& \\
\hline
\end{tabular}

\section{Appendix (continued)}

\begin{tabular}{|c|c|c|}
\hline Name & Location & Contribution \\
\hline $\begin{array}{l}\text { Yemima D. } \\
\text { Berman, BSc } \\
\text { Hons, BMBS, } \\
\text { PhD }\end{array}$ & $\begin{array}{l}\text { Department of Clinical } \\
\text { Genetics, Royal North } \\
\text { Shore Hospital; and Faculty } \\
\text { of Medicine, University of } \\
\text { Sydney, Australia }\end{array}$ & $\begin{array}{l}\text { Drafting/revision of the } \\
\text { manuscript for content, } \\
\text { including medical writing } \\
\text { for content; study concept } \\
\text { or design; analysis or } \\
\text { interpretation of data }\end{array}$ \\
\hline $\begin{array}{l}\text { Nathan Rubin, } \\
\text { MSc }\end{array}$ & $\begin{array}{l}\text { Biostatistics Core, Masonic } \\
\text { Cancer Center, University of } \\
\text { Minnesota, Minneapolis }\end{array}$ & $\begin{array}{l}\text { Analysis or interpretation } \\
\text { of data }\end{array}$ \\
\hline $\begin{array}{l}\text { Melissa Dodds, } \\
\text { MD }\end{array}$ & $\begin{array}{l}\text { Department of } \\
\text { Dermatology, University of } \\
\text { Minnesota, Minneapolis }\end{array}$ & Study concept or design \\
\hline $\begin{array}{l}\text { Scott R. } \\
\text { Plotkin, MD, } \\
\text { PhD }\end{array}$ & $\begin{array}{l}\text { Department of Neurology } \\
\text { and Cancer Center, } \\
\text { Massachusetts General } \\
\text { Hospital, Boston }\end{array}$ & Study concept or design \\
\hline $\begin{array}{l}\text { Claire M.Y. } \\
\text { Wong, MGC }\end{array}$ & $\begin{array}{l}\text { Department of Clinical } \\
\text { Genetics, Royal North } \\
\text { Shore Hospital, Sydney, } \\
\text { Australia }\end{array}$ & Study concept or design \\
\hline $\begin{array}{l}\text { Christopher L. } \\
\text { Moertel, MD }\end{array}$ & $\begin{array}{l}\text { Department of Pediatrics, } \\
\text { University of Minnesota, } \\
\text { Minneapolis }\end{array}$ & $\begin{array}{l}\text { Drafting/revision of the } \\
\text { manuscript for content, } \\
\text { including medical writing } \\
\text { for content; study concept } \\
\text { or design; analysis or } \\
\text { interpretation of data }\end{array}$ \\
\hline
\end{tabular}

\section{References}

1. Uusitalo E, Rantanen M, Kallionpaa RA, et al. Distinctive cancer associations in patients with neurofibromatosis type 1. J Clin Oncol. 2016;34(17):1978-1986.

2. Cimino PJ, Gutmann DH. Neurofibromatosis type 1. Handb Clin Neurol. 2018;148: 799-811.

3. Stewart DR, Korf BR, Nathanson KL, Stevenson DA, Yohay K. Care of adults with neurofibromatosis type 1: a clinical practice resource of the American College of Medical Genetics and Genomics (ACMG). Genet Med. 2018;20(7):671-682.

4. Kim A, Gillespie A, Dombi E, et al. Characteristics of children enrolled in treatment trials for NF1-related plexiform neurofibromas. Neurology. 2009; 73(16):1273-1279.

5. Luckett T, King MT. Choosing patient-reported outcome measures for cancer clinical research: practical principles and an algorithm to assist non-specialist researchers. Eur J Cancer. 2010;46(18):3149-3157.

6. Vranceanu AM, Merker VL, Park ER, Plotkin SR. Quality of life among children and adolescents with neurofibromatosis 1 : a systematic review of the literature. J Neurooncol. 2015;122(2):219-228.

7. Martin S, Wolters PL, Toledo-Tamula MA, et al. Acceptance and commitment therapy in youth with neurofibromatosis type 1 (NF1) and chronic pain and their parents: a pilot study of feasibility and preliminary efficacy. Am J Med Genet Assoc. 2016;170(6):1462-1470.

8. Crawford HA, Barton B, Wilson MJ, et al. The impact of neurofibromatosis type 1 on the health and wellbeing of Australian adults. J Genet Couns. 2015;24(6) 931-944.

9. Wolkenstein P, Zeller J, Revuz J, Ecosse E, Leplege A. Quality-of-life impairment in neurofibromatosis type 1: a cross-sectional study of 128 cases. Arch Dermatol. 2001, 137(11):1421-1425.

10. Page PZ, Page GP, Ecosse E, Korf BR, Leplege A, Wolkenstein P. Impact of neurofibromatosis 1 on quality of life: a cross-sectional study of 176 American cases. Am J Med Genet Assoc. 2006;140(18):1893-1898.

11. Kodra Y, Giustini S, Divona L, et al. Health-related quality of life in patients with neurofibromatosis type 1: a survey of 129 Italian patients. Dermatology. 2009;218(3):215-220.

12. Duong TA, Bastuji-Garin S, Valeyrie-Allanore L, Sbidian E, Ferkal S, Wolkenstein P. Evolving pattern with age of cutaneous signs in neurofibromatosis type 1: a crosssectional study of 728 patients. Dermatology. 2011;222(3):269-273.

13. Ehara Y, Yamamoto O, Kosaki K, Yoshida Y. Natural course and characteristics of cutaneous neurofibromas in neurofibromatosis 1. J Dermatol. 2018;45(1):53-57.

14. Yoshida Y, Ehara Y, Noma H, Yamamoto O. Simple method for estimating cutaneous neurofibromas in patients with neurofibromatosis 1. J Dermatol. 2018;45(5):626-627.

15. Yoshida Y, Ehara Y, Koga M, Imafuku S, Yamamoto O. Epidemiological analysis of major complications requiring medical intervention in patients with neurofibromatosis 1. Acta Derm Venereol. 2018;98(8):753-756. 
Chren MM, Lasek RJ, Flocke SA, Zyzanski SJ. Improved discriminative and evaluative capability of a refined version of Skindex, a quality-of-life instrument for patients with skin diseases. Arch Dermatol. 1997;133(11):1433-1440.

17. Chren MM, Lasek RJ, Quinn LM, Mostow EN, Zyzanski SJ. Skindex, a quality-of-life measure for patients with skin disease: reliability, validity, and responsiveness. J Invest Dermatol. 1996;107(5):707-713.

18. Armstrong AW, Ford AR, Chambers CJ, et al. Online care versus in-person care for improving quality of life in psoriasis: a randomized controlled equivalency trial. J Invest Dermatol. 2019;139(5):1037-1044.
19. Hansson J, Bartley K, Karagiannis T, et al. Assessment of quality of life using Skindex16 in patients with advanced basal cell carcinoma treated with vismodegib in the STEVIE study. Eur J Dermatol. 2018;28(6):775-783.

20. Riccardi VM, Kleiner B. Neurofibromatosis: a neoplastic birth defect with two age peaks of severe problems. Birth Defects Orig Artic Ser. 1977;13(3C):131-138.

21. Lindeman RH, Merenda PF, Gold RZ. Introduction to Bivariate and Multivariate Analysis. Foresman; 1980.

22. Nijsten T, Sampogna F, Abeni D. Categorization of Skindex-29 scores using mixture analysis. Dermatology. 2009;218(2):151-154. 


\section{Neurology}

\section{Measuring the Effect of Cutaneous Neurofibromas on Quality of Life in Neurofibromatosis Type 1 \\ Sheilagh Maguiness, Yemima Berman, Nathan Rubin, et al. Neurology 2021;97;S25-S31 Published Online before print July 6, 2021}

DOI 10.1212/WNL.0000000000012427

This information is current as of July 6, 2021

\section{Updated Information \& Services}

References

Citations

Subspecialty Collections

Permissions \& Licensing

\section{Reprints}

including high resolution figures, can be found at: http://n.neurology.org/content/97/7_Supplement_1/S25.full

This article cites 21 articles, 2 of which you can access for free at: http://n.neurology.org/content/97/7_Supplement_1/S25.full\#ref-list-1

This article has been cited by 1 HighWire-hosted articles: http://n.neurology.org/content/97/7_Supplement_1/S25.full\#\#otherartic les

This article, along with others on similar topics, appears in the following collection(s):

Neurofibromatosis

http://n.neurology.org/cgi/collection/neurofibromatosis Quality of life http://n.neurology.org/cgi/collection/quality_of_life

Information about reproducing this article in parts (figures,tables) or in its entirety can be found online at:

http://www.neurology.org/about/about_the_journal\#permissions

Information about ordering reprints can be found online: http://n.neurology.org/subscribers/advertise

Neurology ${ }^{\circledR}$ is the official journal of the American Academy of Neurology. Published continuously since 1951, it is now a weekly with 48 issues per year. Copyright @ 2021 American Academy of Neurology. All rights reserved. Print ISSN: 0028-3878. Online ISSN: 1526-632X.

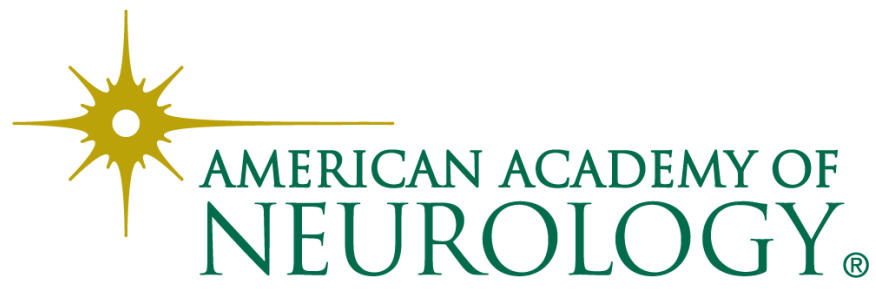

